\title{
超軽量気泡コンクリートに関する研究
}

\section{正会員阿久津 兼二*}

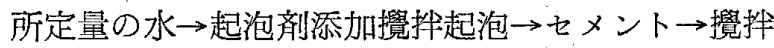

\section{3 試 験 結 果}

$3 \cdot 1$ 比重および圧縮強度 前記 3 秷類の気泡コンク リートの標準モルタル試験体を作り，比重，圧縮強度試 験を行なった結果を第 2 図に示す。偱環送風式電気 定温器内にて $40 \sim 50^{\circ} \mathrm{C}$ に加熱養生を行なった試験結果 を第 3 図に示す。压縮強度の測定は円環型プルービング ・リングを使用した。（写真一 1 参照）

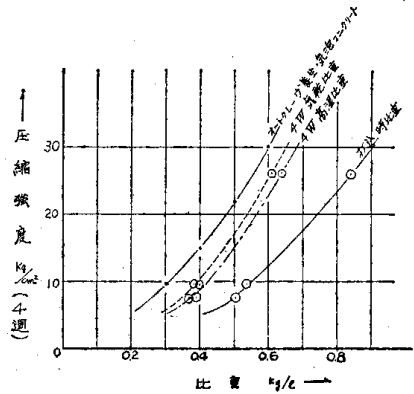

第 2 図 比重と圧縮強度

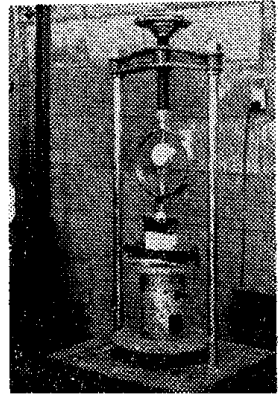

写真-1
重 $0.1 \mathrm{~kg} / l)$

$2 \cdot 2$ 混練および調合 気泡コンクリート用特殊えキ サー（第 1 図参照）圶使用した。攪㐩翼はメタルラスま たは5〜10 mm 目の鉄網を附属せしめたもの。回転数は 150〜300 rpm の笽毌で変速可能な無段変速器を設置し， 攪挫槽は容量 $100 l$ の鉄製タンク忞使用した。

混練方法はつぎのと物りである。

第 2 表実施調合例

\begin{tabular}{|c|c|c|c|c|c|c|c|}
\hline $\begin{array}{c}\text { セメント } \\
\mathrm{kg}\end{array}$ & $\begin{array}{l}\text { 起泡剤 } \\
\% \text { cwt }\end{array}$ & 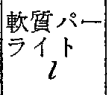 & $\begin{array}{c}\text { 水セx } \\
\text { 卢比 } \\
\%\end{array}$ & 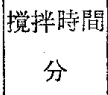 & $\begin{array}{c}\text { 回転数 } \\
\mathrm{rpm}\end{array}$ & $\begin{array}{c}\text { 容 最 } \\
\mathrm{kg} / \mathrm{l}\end{array}$ & $\begin{array}{c}\text { フロー } \\
\mathrm{mm}\end{array}$ \\
\hline 10 & 2.0 & 1.5 & 80 & 5 & 150 & 0.51 & 230 \\
\hline
\end{tabular}

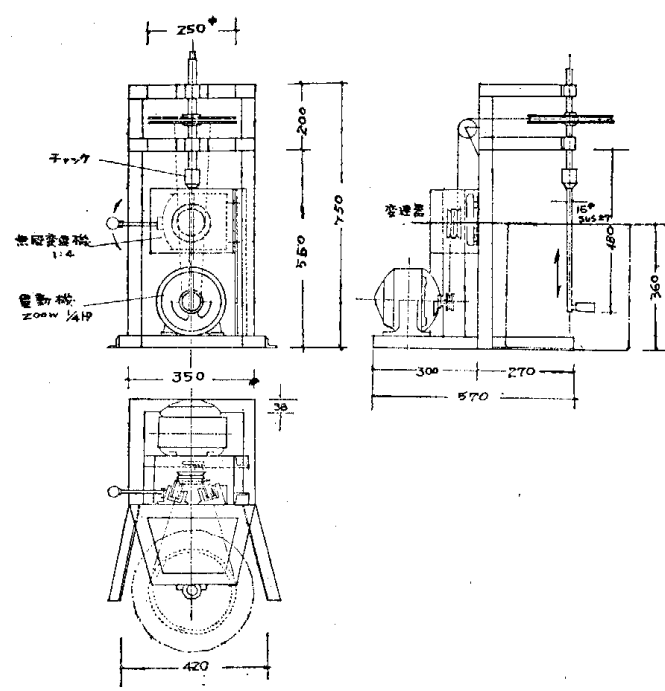

第 1 図 気泡コンクリート製作特殊ミキサー

* 大成建設 $\mathrm{KK}$ 技術研究所員

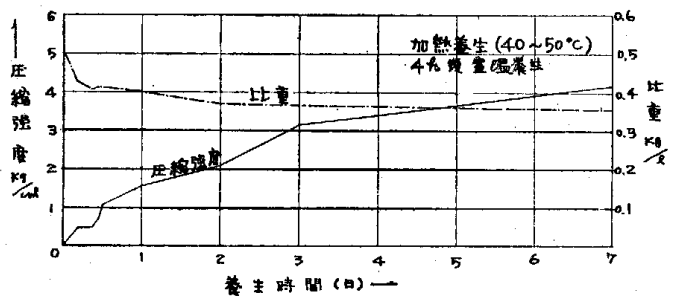

第 3 図 養生時間と比重・圧縮強度

3.2 吸水率 4 種類の表面処理剂（高分子エマルジ ョン，打よび珪酸塩系）を用いて試験体を塗布し，乾燥 後，吸水率を測定した結果は第 4.5 図のと拓りである。

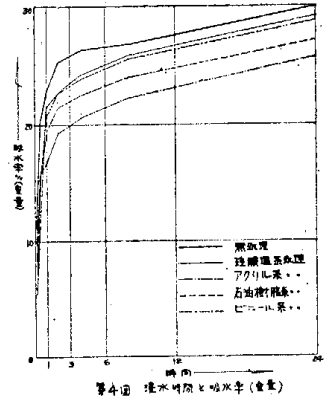

第 4 図 浸水時間々 4 結 言

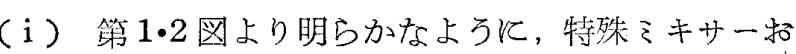
よび適当な混和唎を選执することにより，気乾比重 0.2 〜 0.3 の気泡コンクリートの製作は可能でるる。

(ii) 加熱養生 $\left(40 \sim 50^{\circ} \mathrm{C}\right)$ することにより, 脱型時 闆を著しく短縮できる。

（iii）表面処理制としては醋酸ビニル系，石油樹脂系 の乳剂が有效である。 